\title{
Kemampuan Pemanfaatkan Peranti Kebahasaan dalam Pengonstruksian Teks Resensi melalui Metode Saintifik oleh Peserta Didik SMKN 3 Mataram
}

\author{
Farida Syukroni $^{1}$, Mahsun ${ }^{2}$ dan Lalu Muhaimi ${ }^{3}$ \\ Magister Pendidikan Bahasa Indonesia, \\ Fakultas Keguruan dan Ilmu Pendidikan, Universitas Mataram \\ Jl. Majapahit No.62 Mataram, Nusa Tenggara Barat \\ Posel: aridaonieq16@gmail.com ${ }^{1}, \underline{\text { mahsunirn@gmail.com }}^{2}, \underline{\text { lalu_muhaimi16@unram.ac.id }}$
}

\begin{abstract}
Abstrak. Penelitian ini membahas kemampuan peserta didik memanfaatkan peranti kebahasaan dalam pengonstruksian teks resensi yang dihasilkan melalui metode saintifik. Variabel yang diukur yaitu kemampuan peserta didik memanfaatkan peranti penghubung intrakalimat, peranti penghubung antarkalimat dan peranti penghubung antarparagraf. Keseluruhannya dideskripsikan secara kualitatif dan kuantitatif. Dengan itu, teori relevan yang digunakan adalah teks resensi, konjungsi, reiterasi, perujukan, dan antonimi disertai instrumen penilaian hasil pembelajaran. Pemerolehan data dilakukan dengan metode simak libat cakap atau istilah lainnya disebut observasi partisipatif dengan teknik purposive sampling, simple random sampling, dan sampling sistematis. Selanjutnya, data dianalisis menggunakan metode padan intralingual dan padan ekstralingual dengan teknik hubung banding membedakan (HBB), teknik hubung banding menyamakan (HBS) dan teknik hubung banding menyamakan hal pokok (HBSP) sebagai teknik lanjutan. Terakhir, data disajikan dengan metode informal dan formal. Hasil penelitian menunjukkan bahwa peranti penghubung intrakalimat dimanfaatkan dengan sangat baik dan peranti penghubung antarkalimat digunakan dengan cukup baik. Akan tetapi, peserta didik belum mampu memanfaatkan peranti penghubung antarparagraf dengan baik terutama pada fitur kebahasaan repetisi makna, katafora, antonim dan hiponim. Namun secara keseluruhan, peserta didik dikategorikan cukup mampu memanfaatkan peranti kebahasaan dengan perolehan nilai akhir sebesar 67.
\end{abstract}

Kata kunci: Peranti penghubung intrakalimat, peranti penghubung antarkalimat, peranti penghubung antarparagraf

\section{PENDAHULUAN}

Menulis tidak semata-mata merangkai unit-unit bahasa apalagi hanya sebagai alat penyamapaian pesan. Lebih dari itu, pesan yang ada dalam tulisan memiliki urgensi sebab menyangkut isi hati dan isi pikiran manusia. Unsur kebahasaan dan nonkebahasaan dalam tulisan bagaikan sekeping koin, tidak dapat dipisahkan karena tanpa bahasa pesan itu mustahil tersampaikan.

Sebagai penulis, kegiatan membaca tidak dapat dihindarkan. Hal ini dikarenakan muatan isi atau pesan yang disampaikan dalam tulisan dipengaruhi penguasaan dan pemahaman penulis terhadap suatu persoalan. Penulis dapat mengimplementasikan persoalan tersebut dengan baik melalui kegiatan membaca. Hal ini dikarenakan kedua kegiatan tersebut (baca-tulis) terdapat hubungan timbal balik, penulis sebagai pembaca dan pembaca sebagai penulis.
Sumbangan berharga yang bisa didapati penulis sebagai pembaca berupa ide, gagasan dan informasi, serta menemukan, memperjelas, dan memecahkan masalah, juga mempelajari bagaimana penulis lain menyajikan dan mengemas tulisannya. Sebaliknya, pembaca sebagai penulis juga mendapatkan sumbangan berharga yang sama, bahkan pembaca dapat menganalisis dan mengonstruksi bacaan dengan interpretasi dan imajinya sehingga pesan yang disampaikannya dalam tulisan dapat ditangkap dengan baik oleh pembacanya.

Namun demikian, meski kaya akan ide atau gagasan, persoalan yang dibahas belum tentu tersampaikan secara baik dengan mengabaikan kaidah kebahasaan yang baik dan benar. Tulisan dengan kaidah kebahasaan yang keliru akan membuat pesan yang disampaikan bisa rancu atau ambigu. Oleh karenanya, beberapa peranti kebahasaan 
berperan penting dalam menjaga kekohesifan dan koherensi, baik dalam kalimat, antarkalimat maupun antarparagraf. Selain itu, pemanfaatan kaidah kebahasaan yang baik juga dapat membantu pembaca memahami pesan yang disampaikan penulis dan terhindar dari kesalahpahaman.

Konjungsi, reiterasi, perujukan dan antonimi merupakan pilihan peranti kebahasaan yang dapat dimanfaatkan agar tulisan menjadi lebih apik. Konjungsi terdiri atas konjungsi intrakalimat, antarkalimat dan antarparagraf. Kemudian reiterasi terdiri atas repetisi bentuk, repetisi makna dan hiponim. Sementara itu, perujukan terbagi atas anafora dan katafora.

Konjungsi merupakan hubungan antarklausa yang dapat ditandai dengan kehadiran konjungtor pada awal salah satu klausa tersebut (Alwi dkk., 2010: 395). Tujuannya untuk membentuk hubungan antara satuan bahasa baik itu kata, frasa, kalimat dan paragraf hingga membentuk sebuah teks. Maka dengan adanya konjungsi menjadikan suatu teks terpenuhi syaratnya yakni kohesif dan koheren.

Jenis konjungsi yang pertama disebut konjungsi intrakalimat. Dilihat dari sintaktis dan semantiknya, Chaer (2013: 169-175) dan Warsiman (2013: 33-38) membagi konjungsi menjadi konjungsi koordinatif dan subordinatif. Konjungtor koordinatif menghubungkan dua unsur atau lebih yang sama pentingnya, atau memiliki status yang sama. Sementara konjungtor subordinatif adalah konjungtor yang menghubungkan dua klausa, atau lebih, dan klausa itu tidak memiliki status sintaksis yang sama, salah satu klausa itu merupakan anak kalimat. Contoh koordinatif yaitu dan, serta, dengan bermakna penggabungan sedangkan sebab, karena, lantaran, berhubung merupakan konjungsi subordinatif bermakna penyebab.

Jenis konjungsi yang kedua yaitu konjungsi antarkalimat yang menghubungkan satu kalimat dengan kalimat lain. Konjungtor jenis ini selalu memulai suatu kalimat yang baru dan tentu saja huruf pertamanya ditulis dengan huruf kapital. Contoh Akibatnya, Sebaliknya, Berbeda dengan, Kemudian,
Selanjutnya, Selain itu, Bahkan, Akan tetapi, dan Meskipun demikian.

Jenis konjungsi terakhir yakni konjungsi antarparagraf yang berfungsi sebagai penghubung antara satu paragraf dengan paragraf yang lain. Pada umumnya, Konjungsi antarparagraf terletak pada awal paragraf. Macam-macam konjungsi antarparagraf antara lain: Adapun, Akan hal, Disamping itu, Terlebih lagi, Oleh karena itu, Adapun, Berdasarkan, Selain itu.

Peranti kebahasaan lainya yang penting diperhatikan adalah reiterasi (pernyataan semula) dengan jenis repetisi bentuk. Repetisi bentuk merupakan pengulangan suatu unit leksikal berupa kata, frasa, dan klausa secara menyeluruh atau sebagian, baik antarkalimat maupun antarparagraf. Tujuannya sebagai penekanan atau penegasan agar lebih menarik perhatian serta untuk menyatakan maksud dan tujuan dari kalimat. Kata yang sering diulang ini adalah dari 'kata isi' (content word). Ini bermakna kata itu adalah kata yang sangat penting bagi kalimat yang dibentuk dan dibina bagi teks ataupun wacana. Kata isi boleh dikenal pasti melalui dua cara. Cara yang pertama ialah kata itu atau 'kata isi' tersebut akan dijadikan sebagai unsur yang tidak boleh ditinggalkan ataupun tidak digunakan jika diperkatakan di dalam intipati teks. Manakala cara yang kedua ialah jika kata tersebut tidak diulang maka kemungkinan teks itu akan terganggu sifat kesatuannya (Darma, 2014: 59).

Selain repetisi bentuk, repetisi makna juga merupakan bagian dari reiterasi yang diistilahkan dengan sinonimi. Pengulangan makna ini dapat terbentuk di antara kalimat maupun paragraf. Tujuannya selain untuk menciptakan kalimat yang padu, juga digunakan agar tidak terjadi pengulangan kata yang sama sehingga pendeskripsian dalam teks menjadi lebih menarik. Penggunaan kata-kata yang sama dapat diduga bahwa pembendaharaan seseorang dalam menyampaikan informasi baik lisan maupun tertulis terbatas dan tidak kreatif. Contoh kata yang bersinonim yakni nasib dengan takdir. Contoh tersebut memberikan pengertian bahwa kata-kata yang bersinonim memiliki 
makna yang sama dengan bentuk tulisan yang berbeda sebagaimana penjelasan Verhaar (2012: 394).

Bentuk reiterasi berikutnya disebut dengan superordinat atau hiponim yakni penggunaan kata yang lebih khusus. Verhaar (2012: 396) mengemukakan bahwa hubungan kehiponiman dalam pasangan kata adalah hubungan antara yang lebih kecil (secara ekstensional) dan yang lebih besar (secara ekstensional pula). Misalnya, kursi adalah hiponim terhadap prabot, dan merah merupakan hiponim terhadap warna.

Peranti kebahasaan berupa perujukan juga menjadi poin penting untuk dipahami penulis. Darma (2014: 55-56) menguraikan bahwa perujukan ialah merujuk kepada unsur sebelum atau sesudah yang berkaitan dengan hubungan semantik. Salah satu jenis perujukan yaitu endoforik yang bersifat tekstual terdiri atas perujukan anafora dan perujukan katafora. Darma (2014: 56) menjelaskan bahwa perbedaan perujukan anafora dengan perujukan katafora terletak pada posisi perujuk dan penganjur. Perujuk anafora berada di belakang penganjur, sebaliknya perujuk katafora terletak di depan penganjur. Misal, nya dalam Mas Edi motornya baru. Sedangkan katafora merupakan pengacuan pada sesuatu yang disebut di belakang, misalnya -nya pada kalimat "Dengan gayanya yang khas, ia mulai bicara" mengacu pada ia.

Peranti kebahasaan penting lainnya yakni antonimi yang bertujuan untuk memadukan bagian-bagian teks sehingga mendapatkan struktur antarkalimat yang padu.. Menurut Verhaar (dalam Chaer, 2013:89), antonim didefinisikan sebagai ungkapan (biasanya berupa kata, tetapi dapat pula dalam bentuk frase atau kalimat) yang maknanya dianggap kebalikan dari makna ungkapan lain. Misalnya dengan kata bagus adalah berantonim dengan kata kecil. Contoh lainnya, kata membeli berantonim dengan kata menjual.

Pemanfaatan kaidah-kaidah kebahasaan di atas acapkali terabaikan baik dalam tulisan ilmiah maupun nonilmiah. Sikap tersebut bisa menjadi salah satu faktor penyebab minat dan daya baca masyarakat lemah, terutama akademisi. Untuk mengurangi faktor tersebut, pembiasaan menulis dapat diterapkan secara berkesinambungan dan terbimbing, khususnya kepada pelajar. Kegiatan ini penting dikarenakan pelajar adalah generasi emas pembangun bangsa.

Akan tetapi, banyak pelajar cenderung bersikap apriori yakni beranggapan bahwa menulis adalah kegiatan yang tidak menarik, menjemukan bahkan memfrustasikan. Terkadang kebingungan datang ketika hendak menulis karena kesulitan mengungkapkan ide yang sebetulnya sudah banyak di otak. Banyak juga yang merasa tidak berbakat untuk menulis karena merasa tidak memiliki pemahaman menulis. Pengalaman yang kurang pas ataupun minim dapat juga menjadikan keengganan menulis.

Fenomena tersebut terjadi di SMK Negeri 3 Mataram setelah melihat hasil observasi terhadap hasil kerja mereka dalam memproduksi teks dari berbagai genre yang beragam. Kondisi pelajar yang plural memengaruhi pembendaharaan bahasa mereka sehingga menimbulkan penyimpangan bahasa yang bersifat silap (errors). Misal, "Setelah sari jeruknya terkumpul, tambahkan air dan es batu, gula secukupnya ke dalam gelas. Aduk hingga merata dan tambahkan hiasan agar lebih menarik." Kalimat tersebut merupakan penggalan dari teks prosedur yang dibuat oleh peserta didik. Pemanfaatan konjungsi dan pada kelompok kata air dan es batu, gula secukupnya tidak tepat posisinya sebab bermakna perincian. Posisi yang benar adalah air, es batu dan gula secukupnya. Bahkan, penggalan tersebut tidak menyertakan konjungsi antarkalimat padahal di antara kedua kalimat tersebut dibutuhkan konjungsi subordinatif bersifat kronologis. Demikian halnya dengan konjungsi dan pada kalimat kedua seharusnya diganti dengan konjungsi koordinatif bersifat kronologis juga sebab kedua hal tersebut bermakna pemerian penjelasan tentang suatu tahapan. Akan tetapi, hal tersebut wajar bagi mereka yang merupakan pembelajar bahasa kedua (bahasa Indonesia). Maka dari itu, penting untuk mereka menguasai kaidah-kaidah kebahasaan sebagaimana yang telah diuraikan sebelumnya agar ketika mereka menjadi masyarakat 
seutuhnya dapat dijadikan teladan bagi penulis lainnya.

Salah satu upaya untuk memaksimalkan kemampuan menulis pada pelajar adalah dengan mengarahkan mereka untuk berpikir ilmiah. Mereka dituntut untuk mengembangkan teks secara mandiri dengan menggunakan metode saintifik. Adapun metode saintifik yang diterapkan melalui tahapan yang sistematis. Pertama, pengumpulan data dapat dilakukan dengan berbagai macam metode seperti wawancara, studi pustaka, observasi, mempertanyakan, maupun instropeksi. Selanjutnya dilakukan pengelompokkan data sesui struktur teks. Kedua, analisis data dilakukan dengan cara mengubah data, informasi atau fakta menjadi kalimat-kalimat bahasa Indonesia yang baik dan benar. Selanjutnya dilakukan penggabungan kalimat-kalimat tersebut menjadi paragraf yang mengisi masing-masing struktur teks. kemudian kalimat-kalimat tersebut dibentuk tata bahasanya seperti keefektifan kalimat, penggunaan konjungsi dan sebagainya agar kalimat maupun paragraf menjadi padu. Terakhir, teks dapat dikomunikasikan/disajikan secara lisan maupun tulisan (Mahsun, 2018:122).

Berdasarkan uraian di atas, penelitian ini bermaksud mengevaluasi keterampilan menulis peserta didik di SMK Negeri 3 Mataram yang dikembangkan melalui metode saintifik. Evaluasi pembelajaran ini dimaksudkan untuk menentukan kemampuan peserta didik secara konkrit sebagaimana penjelasan Sudijono (2015:1). Adapun jenis teks yang dievaluasi adalah teks resensi sebagaimana tuntutan kurikulum yang berlaku saat penelitian ini diambil.

Penting diketahui bahwa teks resensi dikategorikan ke dalam genre teks tanggapan dengan subgenre ekspositori. Dilihat dari segi strukturnya, teks resensi masuk sebagai jenis teks reviu/telaah karena terdiri atas mendeskripsikan teks, isi, dan evaluasi. Adapun tujuan sosialnya adalah untuk mengevaluasi teks, teks visual, atau teks musik (lihat Mahsun, 2014: 18-23). Sejalan dengan Kosasih (2014: 46) yang menjelaskan bahwa teks resensi merupakan karangan yang berisi ulasan sebuah karya, baik itu berupa buku, film, maupun album. Kosasih juga menjelaskan di dalam bukunya yang berbeda berjudul Jenis-jenis Teks (2014: 204) bahwa teks ulasan (film/drama) merupakan hasil interpretasi terhadap suatu tayangan atau pementasan drama/film tertentu. Dengan ulasan tersebut, pembaca/penyimaknya menjadi terbantu di dalam memahami suatu tayangan. Dengan sinopsis, seseorang menjadi tahu isi ceritanya secara garis besar. Dengan membaca analisisnya, khalayak menjadi tahu struktur tayangan itu, sekaligus kelebihan dan kelemahannya.

Karena penelitian ini menitikberatkan pada penerapan kaidah kebahasaan dalam teks resensi yang dikonstruksi oleh peserta didik, maka poin yang dibahas mencakup kemampuan peserta didik memanfaatkan peranti penghubung intrakalimat, peranti penghubung antarkalimat dan peranti penghubung antarparagraf dengan ketentuan penilaian berpedoman pada pengembangan penilaian Mahsun (2017:409) sebagaimana terincikan dalam tabulasi berikut.

Tabel 1. Pembobotan Struktur Teks dan Peranti Kebahasaan

\begin{tabular}{|l|l|c|}
\hline No. & \multicolumn{1}{|c|}{ Variabel } & Skor \\
\hline 1. & $\begin{array}{l}\text { Pemahaman Peranti Penghubung } \\
\text { Antarparagraf }\end{array}$ & 4 \\
\hline 2. & $\begin{array}{l}\text { Pemahaman Peranti Penghubung } \\
\text { Antarkalimat }\end{array}$ & 3 \\
\hline 3. & $\begin{array}{l}\text { Pemahaman Struktur } \\
\text { Berpikir/Struktur Teks }\end{array}$ & 2 \\
\hline 4. & $\begin{array}{l}\text { Pemahaman Peranti Penghubung } \\
\text { Intrakalimat }\end{array}$ & 1 \\
\hline \multicolumn{2}{|l|}{ Total Skor } \\
\hline
\end{tabular}

Variabel-variabel di atas diberi bobot penilaian sesuai tingkat kesulitan dan kompleksitas dalam memproduksinya. Namun demikian, penilaian variabel struktur teks tidak disertakan dalam penilaian ini sebab bukan menjadi permasalahan yang dibahas. Oleh karena itu, skor maksimum yang digunakan adalah sebesar 8 , yang dihitung dengan cara pembagian antara jumlah benar dengan total skor kemudian dikali 100.

Selanjutnya, asesmen yang digunakan ialah Penilaian Acuan Patokan (PAP). 
Wahyuni dan Ibrahim (2012:149) memberi pengertian bahwa PAP merupakan penilaian yang dilakukan dengan cara membandingkan skor hasil tes siswa dengan suatu patokan yang telah ditetapkan, yang akan dijadikan standar kelulusan atau pemberian nilai tertentu. Patokan yang dipakai sebagai pembanding hasil belajar dapat berupa persentasi penguasaan materi pelajaran, yang dapat dinyatakan dengan jelas. Tinggi rendahnya persentase yang dituntut untuk dikuasai oleh peserta didik biasanya tergantung pada karakteristik bahan yang diajarkan. Semakin mudah suatu bahan, maka persentasenya semakin tinggi. Semakin sulit suatu bahan, maka persentasenya semakin rendah.

Pengertian di atas relevan dengan perentangan skor penjenjangan kategori kemampuan berbahasa yang ditetapkan oleh Mahsun (2017:413). PAP yang digunakan ialah berskala empat sebagaimana tabulasi berikut.

Tabel 2. Kategori jenjang kemampuan berbahasa

\begin{tabular}{|l|c|c|}
\hline No. & Kategori Jenjang & Skor \\
\hline 1. & Sangat Baik & 91 ke atas \\
\hline 2. & Baik & $79-90$ \\
\hline 3. & Cukup & $67-78$ \\
\hline 4. & Kurang & 66 ke bawah \\
\hline
\end{tabular}

Dengan pengkategorian tersebut akan diperoleh kemampuan konkret peserta didik dalam memanfaatkan peranti kebahasaan yang ditinjau dari hasil pengonstruksian teks resensi melalui metode saintifik.

\section{METODE PENELITIAN}

Pendekatan yang digunakan bersifat kualitatif untuk menjabarkan kemampuan siswa menulis teks resensi. Selanjutnya dilakukan pendekatan kuantitatif dengan menentukan capaian nilai berdasarkan instrumen penilaian. Analisis kuantitatif dibutuhkan sebagai pendukung untuk mengetahui prestasi peserta didik.

Adapun penentuan sampel dilakukan dengan teknik purposive sampling yang menghasilkan sampel terpilih yakni sampel yang menggunakan metode saintifik dalam pengonstruksian teks resensi. Adapun sampel yang dimaksud yaitu jurusan Multimedia: kelas XI MM A sebanyak 22 peserta didik, XI MM B sebanyak 22 peserta didik, dan XI MM C sebanyak 20 peserta didik. Dengan demikian, total keseluruhan sampel sebanyak 64 teks resensi yang bersifat homogen.

Akan tetapi, total teks di atas merupakan jumlah yang banyak untuk dijadikan data kebahasaan sehingga dibutuhkan teknik lanjutan yaitu sampling sistematis untuk memperoleh total sampel dari seluruh kelas dan Simple Random Sampling untuk memperoleh sampel per kelas. Cara pengambilan sampel dengan teknik sampling sistematis yaitu setiap sampel diberi nomor urut berdasarkan waktu pengumpulannya. Dari semua anggota sampel diambil dari kelipatan bilangan 7 sehingga menghasilkan 10 sampel penelitian. Kemudian, teknik Simple Random Sampling digunakan untuk memberikan kesempatan yang sama bagi setiap anggota populasi menjadi sampel penelitian. Cara pengambilannya menggunakan nomor undian. Kesepuluh sampel tersebut berupa teks resensi yang bersifat multimodal, yakni teks yang bersumber dari teks lainnya (tulis/lisan). Meskipun demikian, sampel tetap bersifat homogen karena tujuan akhirnya sama, dimana peserta didik dituntut tunduk pada satu teks yakni mengonstruksi teks resensi.

Proses pemerolehan data menggunakan metode simak libat cakap sebagaimana yang dikemukakan dan diterapkan oleh Mahsun (2017:368) atau sama halnya dengan metode observasi partisipatif yang diimplementasikan oleh Sugiyono (2017:227). Dalam hal ini peneliti terlibat langsung sebagai perencana pembelajaran dan pengajar. Selain itu, metode dokumentasi digunakan sebagai pelengkap berupa hasil kerja peserta didik berbentuk teks tulis. Dengan demikian, sumber data penelitian ini bersifat primer yakni diperoleh secara langsung dari siswa.

Untuk menganalisis data, penelitian ini menggunakna metode padan intralingual dan padan ekstralingual sebagaimana pemahaman Mahsun (2017: 379 dan 397) bahwa metode padan intralingual mengacu pada makna unsur-unsur yang berada dalam bahasa sedangkan metode padan ekstralingual 
mengacu kepada perbandingan kebahasaan dengan nonkebahasaan. Sementara itu, teknik yang digunakan untuk kedua metode tersebut sama, yaitu teknik hubung banding membedakan (HBB), teknik hubung banding menyamakan (HBS) dan teknik hubung banding menyamakan hal pokok (HBSP) sebagai teknik lanjutan.

Prosedur analisis data penelitian secara berurut yakni penentuan variabel, analisis kualitatif lalu analisis kuantitatif. Setelah itu, membandingkan hasil belajar peserta didik secara kualitatif dan kuantitatif menggunakan metode padan intralingual dan padan ekstralingual dengan teknik HBS, HBB, atau HBSP. Terakhir, melalukan pengkategorian untuk menemukan nilai akhir pencapaian belajar seluruh sampel/responden.

Data disajikan dengan metode informal dan formal. Metode informal yaitu perumusan dengan menggunakan kata-kata biasa, termasuk penggunaan terminologi yang bersifat teknis. Sementara metode formal adalah perumusan dengan menggunakan tanda-tanda atau lambang (lihat Mahsun, 2017: 252).

\section{HASIL DAN PEMBAHASAN}

Sebagaimana telah dijelaskan sebelumnya bahwa beberapa peranti kebahasaan yang menghubungkan setiap unit kebahasaan berperan penting dalam menjaga kekohesifan dan koherensi sebuah teks tertulis. Beberapa peranti yang dimaksud ialah konjungsi, reiterasi, perujukan dan anotinimi yang diklasifikasikan menjadi tiga pokok yakni peranti penghubung intrakalimat, peranti penghubung antarkalimat dan peranti penghubung antarparagraf.

Keseluruhan peranti tersebut menjadi variabel yang berhasil dimanfaatkan oleh semua responden. Akan tetapi, banyak pemanfaatan peranti kebahasaan yang tidak kohesif ataupun koheren. Meskipun demikian, tidak sedikit pula yang tepat pengaplikasiannya sebagaimana tabulasi berikut ini.

Tabel 3. Pendeskripsian frekuensi pemakai dan jumlah kemunculan seluruh peranti kebahasaan yang digunakan secara tepat oleh peserta didik

\begin{tabular}{|c|c|c|c|c|}
\hline No. & Variabel & \begin{tabular}{|c|} 
Jumlah \\
Kemunculan
\end{tabular} & $\begin{array}{c}\text { Jumlah } \\
\text { Pengguna }\end{array}$ & $\begin{array}{c}\text { Jumlah } \\
\text { Responden }\end{array}$ \\
\hline \multicolumn{5}{|c|}{$\begin{array}{l}\text { A. Penguasaan Penggunaan Peranti Penghubung } \\
\text { Intrakalimat }\end{array}$} \\
\hline 1 & $\begin{array}{l}\text { Konjungsi } \\
\text { Kesetaraan }\end{array}$ & 142 & 10 & 10 \\
\hline 2 & \begin{tabular}{|l} 
Konjungsi \\
Kebertingkatan
\end{tabular} & 88 & 10 & 10 \\
\hline \multicolumn{5}{|c|}{$\begin{array}{l}\text { B. Penguasaan Penggunaan Peranti Penghubung } \\
\text { Antarkalimat }\end{array}$} \\
\hline 1 & $\begin{array}{l}\text { Repetisi } \\
\text { Bentuk }\end{array}$ & 191 & 10 & 10 \\
\hline 2 & $\begin{array}{l}\text { Repetisi } \\
\text { Makna }\end{array}$ & 40 & 9 & 10 \\
\hline 3 & \multicolumn{4}{|c|}{ Anafora/Katafora } \\
\hline & Anafora & 81 & 10 & 10 \\
\hline & Katafora & 8 & 4 & 10 \\
\hline 4 & Antonim & 22 & 9 & 10 \\
\hline 5 & $\begin{array}{l}\text { Hiponim } \\
\text { (hipernim } \\
\text { personil) }\end{array}$ & 1 & 1 & 10 \\
\hline 6 & $\begin{array}{l}\text { Konjungsi } \\
\text { Antarkalimat }\end{array}$ & 64 & 8 & 10 \\
\hline \multicolumn{5}{|c|}{$\begin{array}{l}\text { C. Penguasaan Penggunaan Peranti Penghubung } \\
\text { Antarparagraf }\end{array}$} \\
\hline 1 & $\begin{array}{l}\text { Repetisi } \\
\text { Bentuk }\end{array}$ & 48 & 9 & 10 \\
\hline 2 & $\begin{array}{l}\text { Repetisi } \\
\text { Makna }\end{array}$ & 8 & 5 & 10 \\
\hline \multirow[t]{3}{*}{3} & \multicolumn{4}{|c|}{ Anafora/Katafora } \\
\hline & Anafora & 14 & 10 & 10 \\
\hline & Katafora & 4 & 3 & 10 \\
\hline 4 & $\begin{array}{l}\text { Antonim: } \\
\text { Cewek-cewek } \\
><\text { cowok }\end{array}$ & 1 & 1 & 10 \\
\hline 5 & $\begin{array}{l}\text { Hiponim: } \\
\text { Para penonton } \\
\text { hipernim anak- } \\
\text { anak }\end{array}$ & 1 & 1 & 10 \\
\hline 6 & $\begin{array}{l}\text { Konjungsi } \\
\text { Antarparagraf }\end{array}$ & 63 & 8 & 10 \\
\hline
\end{tabular}

Tabulasi di atas menunjukkan bahwa peserta didik telah mampu mengungkapkan pikiran dengan memanfaatkan peranti kebahasaan. Kondisi tersebut mengindikasikan bahwa daya ungkap yang dimiliki peserta didik cukup luas. Hal itu ditandai dengan munculnya keseluruhan peranti kebahasaan di setiap variabel.

Anak tetapi, tidak semua variabel dapat dikuasai oleh peserta didik. Dalam tabulasi di atas memperlihatkan kemampuan daya ungkap yang paling minim yaitu hiponim antarkalimat dan hiponim serta antonim antarparagraf. Hal ini menunjukkan kemampuan berpikir untuk sesuatu yang umum masih terbatas sebagaimana fakta yang muncul hanya berjumlah satu dari satu responden.

Pemanfaatan hiponimi antarkalimat hanya digunakan oleh satu responden tersebut berbunyi “...mereka pun mencari dua personil lagi yakni sebagai Drummer dan Keyboardis. Mereka pun berhasil menemukannya, Yayan sebagai Drummer dan Nando sebagai Keyboardis." Diketahui bahwa hiponim 
merupakan bentuk kata khusus yang artinya tercakup dalam kata yang bersifat umum atau hipernim. Pada data tersebut menunjukkan Yayan sebagai Drummer dan Nando sebagai Keyboardis pada kalimat kedua merupakan hiponim dari kata personil pada kalimat pertama.

Hiponimi antarparagraf juga mengalami kondisi yang sama yakni hanya satu kemunculan dari satu pengguna yang memanfaatkan peranti kebahasaan tersebut. Berikut penggalan antarparagrafnya.

"Bahasa yang digunakan dalam film ini adalah bahasa sehari-hari dan bersifat santai sehingga mudah diterima oleh para penonton...."

"Film komedi ini layak ditonton tapi ternyata tidak cocok untuk anak-anak...."

Data di atas menunjukkan frasa para penonton dihubungkan dengan kata ulang pada paragraf berikutnya yaitu anak-anak. Frasa para penonton tergolong hipernim dari kata anak-anak yang juga dapat memunculkan hiponim lainnya seperti remaja dan dewasa.

Demikian juga yang terjadi dengan antonim antarpargaraf bahwa dari semua responden yang diidentifikasi, hanya satu yang memunculkan antonim jenis ini sebagaimana penggalan antarparagraf berikut.

“...Ari adalah seorang Dj terkenal, dia sangat tampan, banyak cewek-cewek yang..."

“...Dan karena Cuma Ara saja yang bisa mengubah image playboynya menjadi cowok yang setia."

Kata cewek pada penggalan paragraf pertama merupakan sebutan untuk perempuan yang masih muda sedangkan kata cowok pada penggalan paragraf berikutnya untuk lelaki yang biasanya masih muda juga. Meski kesamaannya untuk orang yang masih muda namun perbedaan intinya terletak pada gender. Hal lain yang menandakan bahwa kedua kata tersebut bertentangan yakni dari segi bentuknya. Kata cewek-cewek merupakan pengulangan kata yang menandakan bentuk jamak yakni banyak cewek. Sebaliknya, kata cowok merupakan bentuk tunggal.

Dalam pengembangan kalimat, penggunaan konjungsi kesetaraan dan konjungsi kebetingkatan terbilang cukup bagus sebab digunakan oleh seluruh responden dengan jumlah kemunculan yang cukup sering. Misal, pada kalimat setara "Tapi ternyata ada kata-katanya yang vulgar dan ada bahasa gaul yang digunakan susah dimengerti penonton." Kalimat tersebut menyampaikan bahwa ada dua gaya bahasa yang digunakan dalam film yang diresensi yaitu berjenis vulgar; gaul. Oleh karenanya, sangat tepat konjungsi dan dihadirkan untuk menghubungkan diksi yang mengindikasikan gaya bahasa film yang dimaksud (vulgar;gaul). Contoh kalimat lainnya yaitu "Dia cantik, pintar, tetapi sedikit cuek dan jutek.". Penggunaan konjungsi tetapi sebagai bentuk pengontrasan, kemudian digunakan konjungsi dan sebagai penggabungan antarkata. Berikutnya, contoh kalimat bertingkat "Contohnya tokoh-tokoh yang mati tanpa diketahui siapa pembunuhnya." Kalimat tersebut menggunakan konjungtor tanpa sebagai petunjuk bahwa kalimat tersebut menyampaikan keadaan para tokoh dalam film yang diresensi. Contoh lainnya seperti "Bahasa yang digunakan dalam film ini adalah bahasa sehari-hari dan bersifat santai sehingga mudah diterima oleh para penonton." Kalimat tersebut menggunakan konjungsi subordinatif sehingga yang bermakna akibat atau hasil. Dalam konteks ini penggunaan bahasa dalam film yang diresensi menjadikan film tersebut layak ditonton.

Akan tetapi, pengembangan kalimat majemuk bertingkat lebih terbatas dibanding kalimat majemuk setara. Hal ini dikarenakan banyak pemanfaatan konjungsi kebertingkatan yang tidak tepat dari responden. Misal, Sebagaimana halnya dengan konjungsi kesetaraan, konjungsi kebertingkatan juga memiliki peran penting dalam menghubungkan antarklausa agar tetap kohesif. Namun juga, tidak semua responden memanfatkannya dengan baik. Misal dalam kalimat "Kemudian apabila berbicara dengan suasana tokoh utama yang sangat sibuk 
dengan pekerjaan kantornya daripada keluarga di rumah." Kalimat tersebut memperlihatkan kalimat yang kacau secara kohesif sehingga secara koheren sangat sulit diterima. Ini dibuktikan dengan digunakannya konjungsi apabila dan daripada yang keduanya berbeda makna sehingga kalimat menjadi rancu. Diketahui, konjungsi apabila digunakan untuk menyatakan syarat atau kondisi yang harus dipenuhi sedangkan konjungsi daripada digunakan untuk menyatakan perbandingan. Hal yang bertentangan ini mengakibatkan pembaca sulit memahami maksud kalimat.

Peranti penghubung kalimat dan peranti penghubung paragraf didominasi dengan repetisi bentuk dibanding repetisi makna. Hal ini menunjukkan penguasaan sinonim siswa terbatas. Bahkan, tidak semua responden menggunakan peranti tersebut. Artinya, ada responden yang tidak mampu menguasai repetisi bentuk ataupun repetisi makna (sinonim).

Adapun kalimat-kalimat lainnya yang dihasilkan responden yakni repetisi bentuk antarkalimat "Mereka di undang untuk hangout di sebuah pulau terpencil. Mereka di undang ke sana untuk membicarakan sebuah proyek dengan sejumlah uang besar". Pengulangan frasa Mereka di undang (red: mereka diundang) dan konjungsi untuk dalam kalimat tersebut menegaskan maksud kalimat yakni menjelaskan tentang dua tujuan para tokoh (mereka) datang (diundang) ke pulau terpencil. Contoh lainnya yaiut "Namanya adalah Ari Irham, dipanggil Ari. Ari adalah seorang DJ muda...". Dalam dua kalimat tersebut mengulang kata adalah dan Ari yang menjelaskan maksud hubungan kalimat tersebut hendak mendefinisikan tokoh si Ari.

Selanjutnya, repetisi makna antarkalimat yang berbunyi "Menceritakan berbagai konflik persahabatan dan percintaan yang merupakan realita kehidupan remaja. Dan mengajarkan bagaimana sikap untuk menghadapi setiap permasalahan yang ada." Kata konfilk pada klimat pertama yang dihubungkan dengan kata permasalahan pada kalimat kedua. Konflik berarti perselisihan atau pertentangan. Sementara itu, permasalahan berarti sesuatu hal yang dipermasalahkan atau dipersoalkan. Baik itu perselisihan, pertentangan dan persoalan umumnya melibatkan dua pihak sehingga kata konflik dan permasalahan dikatakan memiliki kesamaan makna atau bersinonim.

Contoh lainnya pada tingkatan antarparagraf dari segi repetisi bentuk berbunyi:

"Keunggulan lain film Coco adalah latar tempat dan suasana yang digunakan bernuansa kota Mexico sehingga budaya Mexico terlihat sangat kuat dalam film ini. Misalnya banyak lagu-lagu Mexico yang diperdengarkan sehingga menjadikan ciri khas film tersebut. Latarnya juga mampu menguatkan cerita tertutama karakter setiap tokoh memiliki ciri khas masing-masing. Mereka tidak terlepaskan dari ciri khas orang Mexico.

Karena budaya Mexico sangat kental dalam film ini jadi banyak istilah mexico yang digunakan. Akan tetapi istilahistilah itu minim penjelasan sehingga penonton harus mencari sumber bacaan lain untuk memahami istilah-istilah itu."

Di antara dua paragraf yang tersusun urut tersebut terdapat repetisi kata di awal paragraf yakni Mexico. Kata tersebut mengindikasikan bentuk penegasan bahwa responden memiliki maksud tertentu. Dapat diinterpretasikan bahwa penekanan pada kata Mexico bertujuan untuk menjelaskan karakter dan identitas kota Mexico.

Sementara itu, pada variabel repetisi makna antarparagraf berbunyi:

"Film Yowis Ben memiliki alur campuran, pada awal cerita menggunakan..."

"Cerita dari Film Yowis Ben adalah cerita yang berdasarkan..."

Kata alur pada penggalan paragraf pertama, dalam konteks sastra diartikan sebagai jalan cerita. Tidak berbeda dengan kata cerita pada penggalan paragraf setelahnya, memiliki arti rangkaian peristiwa atau kejadian. Maka dari itu, kedua kata tersebut dikatakan bersinonim. 
Sementara itu, posisinya yang terletak di antara dua paragraf yang berbeda dikatakan sebagai repetisi makna antarparagraf.

Berdasarkan tabulasi di atas juga memperlihatkan kemampuan mengontraskan gagasan antarkalimat cukup baik. Hal ini ditandai dengan jumlah kemunculan antonim lebih besar dibanding jumlah responden. Meskipun demikian, ada satu responden yang tidak memanfaatkan peranti tersebut sehingga dinilai tidak mampu menguasai.

Berikut adalah beberapa contoh ragam antonimi antarkalimat yang dihasilkan para responden. Antarkalimat pertama, "Karena budaya Mexico sangat kental dalam film ini jadi banyak istilah mexico yang digunakan. Akan tetapi istilah-istilah itu minim penjelasan sehingga penonton harus mencari sumber bacaan lain untuk memahami istilahistilah itu." Kata minim dalam kalimat kedua tersebut bersinonim dengan kata sedikit yang merupakan lawan kata dari banyak pada kalimat pertama. Antarkalimat berikutnya, "Ketika pertama kali bertemu, Kugy sedang menjalin kasih dengan Ojos, Pria tampan yang telang ia pacari semenjak masa sekolah masa SMA. Kenan sendiri juga sempat dekat dengan seorang gadis cantik bernama Wanda." Di antara dua kalimat tersebut terdapat dua frasa yang saling bertentangan yaitu pria tampan dan gadis cantik. Contoh antarkalimat terakhir yaitu "Gas tersebut juga tidak terlalu berbahaya apabila sedikit terhirup. Akan tetapi, gas tersebut akan sangat berbahaya apalagi..." Antarkalimat tersebut memperlihatkan dua frasa yang bermakna berlawanan yaitu tidak terlalu berbahaya berantonim dengan frsasa sangat berbahaya.

Sebaliknya, sebagian besar responden belum mampu mengontraskan gagasan antarparagraf yang ditandai dengan kemunculan antonim berjumlah satu dari satu responden Adapun penggalan data yang dimaksud berbunyi:

“...Ari adalah seorang Dj terkenal, dia sangat tampan, banyak cewek-cewek yang...”

“...Dan karena Cuma Ara saja yang bisa mengubah image playboynya menjadi cowok yang setia."
Kata cewek pada penggalan paragraf pertama merupakan sebutan untuk perempuan yang masih muda sedangkan kata cowok pada penggalan paragraf berikutnya untuk lelaki yang biasanya masih muda juga. Meski kesamaannya untuk orang yang masih muda namun perbedaan intinya terletak pada gender. Hal lain yang menandakan bahwa kedua kata tersebut bertentangan yakni dari segi bentuknya. Kata cewek-cewek merupakan pengulangan kata yang menandakan bentuk jamak yakni banyak cewek. Sebaliknya, kata cowok merupakan bentuk tunggal.

Hal lain yang dapat diperhatikan pada tabulasi di atas adalah tidak semua responden mampu memanfaatkan peranti penghubung antarkalimat dengan baik. Bahkan, dua responden tidak memanfaatkan peranti tersebut sehingga dinilai tidak memiliki penguasaan menghubungkan antarkalimat. Misal dalam beberapa contoh ini tampak responden belum bisa membedakan konjungsi antarkalimat dengan konjungsi intrakalimat sebagaimana dalam penggalan kalimat yang berbunyi "Pada saat itu sepulang sekolah..." dan "Meskipun Nathan sering merasa..." memiliki konjungtor antarkalimat yang tepat. Konjungsi pada saat itu pada contoh kalimat pertama bertujuan untuk menyatakan waktu sedangkan contoh berikutnya, konjungsi meskipun digunakan untuk menyatakan perbedaan atau pertentangan. Berbeda halnya dengan penggalan kalimat "Dan mengajarkan kita pentingnya..." dan "Sehingga sangat layak..." Konjungtor dan dan sehingga dalam dua penggalan kalimat tersebut merupakan bentuk konjungsi intrakalimat yang idealnya dimanfaatkan sebagai penghubung antarkata, antarfrasa ataupun antarklausa.

Demikian halnya dengan konjungsi antarparagraf bahwa tidak semua responden memanfaatkan konjungsi antarparagraf dengan baik. Misal, dalam penggalan paragraf yang berbunyi "Dan saat Daniel meninggal dunia ibu dari saudara kembar ini..." menunjukkan bahwa responden tidak mampu membedakan konjungsi antarparagraf dengan konjungsi intrakalimat. Hal tersebut terlihat jelas pada konjungsi dan yang digunakan pada 
awal kalimat dalam paragraf. Akan tetapi, ada bentuk konjungsi antarparagraf yang digunakan secara tepat oleh responden, misalnya pada penggalan paragraf yang berbunyi "Akan tetapi, latar tempat seperti gerbong kereta yang membuat penonton gemas." Konjungsi akan tetapi yang diletakkan pada awal kalimat dalam paragraf serta dibubuhi tanda baca koma setelahnya merupakan ciri dari konjungsi antarparagraf.

Setelah mendeskripsikan secara kualitatif kinerja para responden, langkah berikutnya yaitu membandingkan hal di luar kebahasaan dengan metode padan ekstralingual. Fokus pembahasan pada tahap ini adalah membandingkan pembelajaran bahasa antarkelas pada suatu jurusan. Hal ini perlu untuk mengungkap perbedaan kemampuan siswa pada jurusan Multimedia (MM) dalam memahami pemanfaatan peranti kebahasaan. Penting dipertegas bahwa responden penelitian ini terdiri atas 3 sampel kelas XI MM A, 3 sampel kelas XI MM B, dan 4 sampel kelas XI MM C.

Namun demikian, untuk mencapai hal tersebut diperlukan pembobotan terhadap masing-masing variabel. Pemahaman peranti penghubung paragraf diberi skor 4, pemahaman peranti penghubung antarkalimat diberi skor 3, pemahaman struktur berpikir diberi skor 2, dan pemahaman peranti penghubung intrakalimat diberi skor 1. Peranti penghubung antarparagraf memiliki skor tertinggi karena kemampuan tersebut membutuhkan kesulitan dan kompleksitas yang tinggi daripada peranti lainnya. Akan tetapi, pemahaman terhadap struktur teks tidak dibahas maka tidak perlu dinilai. Dengan demikian, total maksimal skor sebanyak 8 (80). Penyekoran ini juga menjadi tolok ukur pencapaian kinerja seluruh responden.

Hasil kuantitatif memperlihatkan bahwa penerapan peranti penghubung intrakalimat tidak ada yang lebih unggul. Artinya, seluruh siswa memiliki kemampuan yang sama yakni "sangat baik" dalam memanfaatkan peranti penghubung intrakalimat dalam mengembangkan gagasan. Hal ini terlihat dari perolehan skor maksimal ketiga kelas yaitu 10 .
Berbeda halnya dengan peranti kebahasaan antarkalimat, kelas XI MM A lebih unggul kemudian diikuti kelas XI MM B lalu XI MM C dengan perbandingan skor 24,28:21,24:20,35. Diketahui bahwa bobot maksimal peranti kebahasaan ini adalah 30 . Apabila dihitung perolehan nilainya, jumlah skor dapat dibagi bobot maksimal dan dikalikan 100 sehingga perbandingan nilai yang diperoleh yaitu 80,9:70,8:67,8 dengan rerata nilai 73,16. Maka, kategori kemampuan siswa kelas XI, jurusan Multimedia dalam memanfaatkan peranti penghubung antarkalimat sesuai daftar penjenjangan skor dalam Mahsun (2017:413) yaitu "cukup".

Tingkat keunggulan yang sama juga diperoleh kelas XI MM A dalam mengaplikasikan peranti penghubung paragraf untuk mengembangkan gagasan mereka. Skor yang didapat yaitu 26,64 sedangkan kelas XI MMB memperoleh skor 24,74 dan XI MM C sebesar 14,28 . Jika jumlah skor yang didapat dibagi jumlah bobot maksimal (40) dan dikalikan 100 maka nilai yang diperoleh ketiganya adalah 66,6:61,85:35,7. Adapun rerata nilai yang diperoleh adalah 54,71. Dengan demikian, kemampuan siswa kelas XI, jurusan Multimedia dalam memanfaatkan peranti penghubung antarparagraf sesuai daftar penjenjangan skor dalam Mahsun (2017:413) dikategorikan "kurang".

Selanjutnya, hasil akhir kinerja peserta didik kelas XI jurusan Multimedia di SMK Negeri 3 Mataram dalam mengonstruksi teks resensi melalui metode saintifik memiliki kemampuan penguasaan peranti kebahasaan yang cukup. Pengkategorian ini didasari perentangan skor penjenjangan kategori kemampuan memproduksi teks oleh Mahsun (2017:413). Adapun nilai akhir yang diperoleh sebesar 67.

\section{KESIMPULAN}

Kemampuan peserta didik jurusan Multimedia kelas XI dalam memanfaatkan peranti kebahasaan memiliki keberagaman. Pertama, pada aspek pengembangan kalimat majemuk setara dan kalimat majemuk bertingkat dikategorikan sangat baik sebab skor yang diperoleh ketiga kelas adalah skor 
maksimal. Kedua, kemampuan menghubungkan kalimat yang satu dengan yang lain dengan memanfaatkan peranti penghubung antarkalimat terbilang cukup. Ketiga, kemampuan memadu padankan antara paragraf yang satu dengan yang lain menunjukkan bahwa ketiga kelas belum mampu menguasai peranti penghubung antarparagraf tersebut terutama pada fitur kebahasaan repetisi makna, katafora, antonim dan hiponim. Namun demikian, hasil akhir menunjukkan bahwa peserta didik jurusan Multimedia kelas XI cukup mampu memanfaatkan peranti kebahasaan dalam pengonstruksian teks resensi melalui metode saintifik.

\section{SARAN}

Berdasarkan hasil akhir evaluasi pembelajaran, peserta didik perlu dilatih secara berkesinambungan untuk meningkatkan kreativitas dalam menguasai peranti kebahasaan terutama peranti penghubung antarparagraf yang memiliki kompleksitas kesulitan tertinggi, kemudian disusul dengan peranti penghubung antarkalimat.

Di dalam penelitian ini ada hal yang belum terealisasi yaitu evaluasi pelaksanaan kegiatan menulis teks resensi dengan metode saintifik, yaitu perubahan kata menjadi kalimat, kalimat menjadi paragraf, dan paragraf menjadi wacana. Harapan akan hal itu dapat dilanjutkan baik oleh peneliti sendiri maupun peneliti lain meskipun terhadap teks yang berbeda.

\section{UCAPAN TERIMA KASIH}

Ucapan terima kasih disampaikan kepada Bapak Mahsun, dan Bapak Lalu Muhaimi yang telah berkenan memberikan saran dan kritikan terkait proses pengolahan data penelitian. Terima kasih pula kepada rekan-rekan SMKN 3 Mataram yang telah memberikan waktu untuk observasi di kelas masing-masing sebagai perbandingan sampel. Terakhir, terima kasih kepada semua pihak yang membantu baik secara materi, finansial maupun administratif.

\section{DAFTAR PUSTAKA}

Alwi, Hasan, dkk. 2010. Tata Bahasa Baku Bahasa Indonesia. Jakarta: Balai Pustaka.

Chaer, Abdul. 2013. Pengantar Semantik Bahasa Indonesia. Jakarta: PT Rineka Cipta

Darma, Yoce Aliah. 2014. Analisis Wacana Kritis dalam Multiperspektif. Bandung: PT Refika Aditama.

Kosasih, E. 2014. Dasar-dasar Keterampilan Menulis. Bandung: Yrama Widya.

Kosasih, E. 2014. Jenis-jenis Teks. Bandung: Yrama Widya.

Mahsun. 2014. Teks dalam Pembelajaran Bahasa Indonesia Kurikulum 2013. Jakarta: PT Raja Grafindo Persada.

Mahsun. 2017. Metode Penelitian Bahasa: Tahapan, Strategi, Metode, dan Tekniknya. Jakarta: PT Raja Grafindo Persada.

Mahsun. 2018. Pembelajaran Bahasa Indonesia Berbasis Teks. Jakarta: PT Raja Grafindo Persada.

Sudijono, Anas. 2015. Pengantar Evaluasi Pendidikan. Jakarta: PT Raja Grafindo Persada.

Sugiyono. 2017. Metode Penelitian (Kuantitatif, Kualitatif, dan $R \& D$ ). Bandung: CV. Alfabeta.

Verhaar. 2012. Asas-asas Linguistik Umum. Yogyakarta: Gadjah Mada University Press.

Wahyuni, Sri dan Abd. Syukur Ibrahim. 2012. Asesmen Pembelajaran Bahasa. Bandung: PT Refika Aditama.

Warsiman. 2013. Bahasa Indonesia Ilmiah untuk Penulisan Laporan, Skripsi, Tesis, dan Disertasi. Malang: UB Press. 